\title{
PENGARUH MODEL PEMBELAJARAN ACTIVE DEBATE BERNUANSA OUTDOOR STUDY TERHADAP KOMPETENSI PENGETAHUAN IPS SISWA
}

\author{
Ni Made Yuana Dewi ${ }^{1}$, Ida Bagus Gede Surya Abadi² , Made Putra ${ }^{3}$ \\ 1 Jurusan Pendidikan Dasar, Universitas Pendidikan Ganesha, Singaraja, Indonesia \\ 2 Jurusan Pendidikan Dasar, Universitas Pendidikan Ganesha, Singaraja, Indonesia \\ 3 Jurusan Pendidikan Dasar, Universitas Pendidikan Ganesha, Singaraja, Indonesia \\ e-mail : made.yuana.dewi@undiksha.ac.id ${ }^{1}$ idabagusgedesurya.abadi@undiksha.ac.id², madeputra@undiksha.ac.id³
}

\begin{abstract}
Abstrak
Penelitian ini bertujuan untuk mengetahui pengaruh model pembelajaran Active Debate bernuansa outdoor study terhadap kompetensi pengetahuan IPS siswa kelas V SD N Gugus Kapten Japa tahun ajaran 2018/2019. Jenis penelitian ini adalah penelitian eksperimen semu dengan rancangan non-equivalent control group design. Populasi dalam penelitian ini sebanyak 12 kelas. Sampel penelitian ditentukan dengan teknik random sampling dengan mengacak kelas. Sampel dalam penelitian ini adalah kelas VB SD N.17 Dauh Puri sebagai kelompok eksperimen sebanyak 42 siswa dan kelas V SD N. 20 Dangin Puri sebagai kelompok kontrol sebanyak 36 siswa. Data kompetensi pengetahuan IPS dikumpulkan dengan instrumen berupa tes objektif bentuk pilihan ganda biasa berjumlah 30 butir tes yang telah divalidasi. Data kompetensi pengetahuan IPS dianalisis dengan uji-t polled varian. Berdasarkan hasil analisis uji-t diperoleh $t_{\text {hitung }}=2,667$. Harga tersebut kemudian dibandingkan dengan harga tabel dengan $\mathrm{dk}=76$ dan taraf signifikansi 5\% sehingga diperoleh harga $t_{\text {tabel }}=2,000$, karena $t_{\text {hitung }}=2,667>$ $t_{\text {tabel }}=2,000$ sehingga $\mathrm{H}_{0}$ ditolak. Demikian pula rerata kompetensi pengetahuan IPS siswa kelompok eksperimen $\overline{\boldsymbol{X}}=0,50$ lebih besar dibandingkan dengan rerata kompetensi pengetahuan IPS siswa kelompok kontrol $\overline{\boldsymbol{X}}=0,42$. Dengan demikian dapat disimpulkan, model pembelajaran Active Debate bernuansa outdoor study berpengaruh terhadap kompetensi pengetahuan IPS siswa kelas V SD N Gugus Kapten Japa tahun ajaran 2018/2019. Berdasarkan hasil penelitian bahwa hasil penelitian ini dapat dijadikan sebagai kajian yang relevan khususnya sebagai referensi bagi peneliti dengan kajian yang luas dan memperdalam teori mengenai model pembelajaran Active Debate bernuansa outdoor study.
\end{abstract}

Keywords:

Pembelajaran active debate, outdoor study, kompetensi pengetahuan IPS 


\section{PENDAHULUAN}

Pendidikan merupakan suatu hal yang sangat penting bagi kehidupan manusia karena melalui pendidikan manusia belajar, sehingga wujud perubahan dari tidak tahu menjadi tahu dan dari tidak mengerti menjadi mengerti. Pendidikan itu sendiri adalah suatu proses dalam rangka mempengaruhi peserta didik supaya mampu menyesuaikan diri sebaik mungkin dengan lingkungannya, dan dengan demikian akan menimbulkan perubahan dalam dirinya yang memungkinkannya untuk berfungsi secara adekwat dalam kehidupan masyarakat (Hamalik, 2013). Oleh karena itu, peningkatan mutu pendidikan adalah tindakan secara terus menerus harus dilakukan demi tercapainya perubahan-perubahan yang diharapkan terjadi dalam proses pembelajaran. Dalam rangka peningkatan mutu pendidikan, pemerintah telah menerapkan kurikulum tahun 2013 untuk sekolah/ madrasah.

Kurikulum dalam Undang-Undang Nomor 20 Tahun 2003 tentang Sistem Pendidikan Nasional merupakan seperangkat rencana dan peraturan mengenai tujuan, isi, dan bahan pelajaran serta cara yang digunakan sebagai pedoman penyelenggaraan kegiatan pembelajaran untuk mencapai tujuan pendidikan tertentu. Kurikulum 2013 dirancang dengan tujuan untuk mempersiapkan insan Indonesia supaya memiliki kemampuan hidup sebagai pribadi dan warganegara yang beriman, produktif, kreatif, inovatif, dan afektif serta mampu berkontribusi pada kehidupan masyarakat, berbangsa, bernegara dan peradaban dunia (Dirman dan Juarsih, 2014). Tujuan Pendidikan Nasional sebagaimana telah dirumuskan dalam Undang-Undang Nomor 20 Tahun 2003 tentang Sistem Pendidikan Nasional adalah untuk berkembangnya potensi peserta didik agar menjadi manusia yang beriman dan bertakwa kepada Tuhan Yang Maha Esa, berakhlak mulia, sehat, berilmu, cakap, kreatif, mandiri, dan menjadi warga negara yang demokratis serta bertanggung jawab. Secara singkatnya, undang-undang tersebut berharap pendidikan dapat membuat peserta didik menjadi kompeten dalam bidangnya.

Kurikulum 2013 menerapkan pendekatan saintifik pada setiap pembelajaran yang dilaksanakan. Pada pelaksanaan pembelajaran dengan pendekatan saintifik, guru perlu merancang berbagai kegiatan sesuai dengan karakteristik anak usia SD pada umumnya meliputi senang bergerak, senang bermain, senang melakukan sesuatu secara langsung dan senang bekerja dalam kelompok. Untuk meningkatkan kompetensi pengetahuan siswa dibutuhkan suatu perubahan pembelajaran yang mengikutsertakan siswa turut aktif sehingga merangsang minat belajar siswa dalam proses pembelajaran. Peranan guru dalam proses pembelajaran sangat diperlukan untuk mengembangkan potensi dan keberhasilan siswa dalam belajar agar tujuan yang diinginkan tercapai.

Berdasarkan informasi yang diperoleh saat pelaksanaan observasi dari guru kelas V di SD $\mathrm{N}$ Gugus Kapten Japa dalam pembelajaran berkaitan dengan muatan materi IPS terutama kompetensi pengetahuan, karena pembelajaran hanya berdasarkan buku pegangan siswa sehingga kurang kreatif dan membuat siswa kurang tertarik terhadap pembelajaran. Secara tidak langsung pola pembelajaran seperti itu akan membuat pencapaian kompetensi siswa menjadi tidak optimal. Berdasarkan informasi yang diperoleh teridentifikasi masalah seperti : (1) Partisipasi siswa masih rendah dalam mengikuti kegiatan pembelajaran hal ini terbukti saat bertanya dan menjawab muatan materi IPS, (2) Hanya beberapa siswa saja yang berani mengutarakan pendapatnya, sedangkan siswa yang lain hanya sebagai pendengar, (3) Interaksi yang kurang dalam pelaksanaan bekerja kelompok, (4) Kurangnya pemahaman siswa dalam belajar materi IPS.

Pelaksanaan pembelajaran perlu didesain secara kreatif dan inovatif dengan memperhatikan karakteristik perkembangan siswa kelas V SD N Gugus Kapten Japa. Dari permasalahan ditemukan dipandang perlu adanya inovasi dalam pembelajaran yakni pembelajaran yang mengutamakan kompetensi pengetahuan, berpusat pada siswa, memberikan 
pengalaman belajar, dan mampu mengajak siswa untuk berperan aktif dalam kegiatan pembelajaran. Model Pembelajaran inovasi yang dimaksud adalah model pembelajaran yang dapat memberikan kesempatan kepada siswa untuk membangun pengetahuannya sendiri serta terlibat secara aktif dengan mengemukakan pendapat dalam proses pelaksanaan pembelajaran yang juga akan berdampak dengan pencapaian kompetensi siswa dan kemampuan siswa dalam berpikir kritis. Model Pembelajaran inovasi yang dimaksud adalah model pembelajaran Active Debate (Debat Aktif).

Model pembelajaran Active Debate (Debat Aktif) merupakan salah satu model pembelajaran yang sangat penting untuk meningkatkan kemampuan akademik siswa. Model pembelajaran debat merupakan kegiatan adu pendapat atau argumentasi antara dua pihak atau lebih, baik secara perorangan maupun kelompok, dalam mendiskusikan dan memutuskan masalah dan perbedaan. Debat aktif bisa menjadi sebuah model pembelajaran berharga yang dapat mendorong pemikiran dan perenungan terutama kalau peserta didik bisa aktif mempertahankan pendapat yang bertentangan dengan keyakinan masing-masing. Hal ini merupakan strategi yang secara aktif melibatkan setiap siswa didalam kelas (Shoimin, 2014:25). Menurut Kurniasih dan Sani (2015:64), "model pembelajaran debat aktif merupakan modifikasi dari model-model diskusi terbuka yang terjadi di kalangan pelajar dan mahasiswa". Adapun langkah-langkah dari model pembelajaran Active Debate (Debat Aktif) yakni a)Guru membagi kelompok peserta debat yang satu pro dan yang lainnya kontra, b) Guru memberikan tugas untuk membaca materi yang akan di debatkan oleh kedua kelompok di atas, c) Setelah selesai membaca materi. Guru menunjuk salah satu anggota kelompok pro untuk berbicara saat itu ditanggapi atau dibalas oleh kelompok kontra demikian seterusnya sampai sebagian besar siswa bisa mengemukakan pendapatnya, d) Sementara siswa menyampaikan gagasannya, guru menulis inti/ide-ide dari setiap pembicaraan di papan tulis. Sampai sejumlah ide yang diharapkan guru terpenuhi, e) Guru menambahkan konsep/ide yang belum terungkap, f) Dari data-data di papan tersebut, guru mengajak siswa membuat kesimpulan/rangkuman yang mengacu pada topik yang ingin dicapai.

Setiap model pembelajaran yang diterapkan dalam kegiatan pembelajaran tentu memiliki kelebihan. Kurniasih dan Sani (2015:64) menyebutkan "kelebihan model pembelajaran Active Debate (Debat Aktif) yaitu sebagai berikut: (1) Memantapkan pemahaman konsep siswa terhadap materi pelajaran yang telah diberikan, (2) Melatih siswa untuk bersikap kritis terhadap semua teori yang telah diberikan, (3) Melatih siswa untuk berani mengemukakan pendapat".

Suatu perdebatan dapat menjadi sebuah metode berharga untuk mengembangkan pemikiran dan refleksi, khususnya jika para peserta didik diharapkan mengambil posisi yang bertentangan dengan pendapatnya. Ini adalah sebuah strategi untuk perdebatan yang secara aktif melibatkan setiap peserta didik dalam kelas, bukan hanya orang-orang yang terlibat (Silberman, 2007).

Ilmu Pengetahuan Sosial adalah mata pelajaran di sekolah yang didesain atas dasar fenomena, masalah dan realitas sosial dengan pendekatan interdispliner yang melibatkan berbagai cabang ilmu-ilmu sosial dan humaniora seperti kewarganegaraan, sejarah, geografi, ekonomi, sosiologi, antropologi, pendidikan (Zubaedi, 2011). Pernyataan tersebut didukung dalam pernyataan (Trianto, 2012) yang menjelaskan bahwa Ilmu Pengetahuan Sosial (IPS) merupakan integrasi dari berbagai cabang ilmu-ilmu sosial, seperti sosiologi, sejarah, geografi, ekonomi, politik, hukum, dan budaya. Ilmu Pengetahuan Sosial dirumuskan atas dasar realitas dan fenomena sosial yang mewujudkan satu pendekatan interdisipliner dari aspek dan cabangcabang ilmu-ilmu sosial (sosiologi, sejarah, geografi, ekonomi, politik, hukum, dan budaya). Ilmu pengetahuan sosial juga membahas hubungan antara manusia dengan lingkungannya. Lingkungan masyarakat dimana anak didik tumbuh dan berkembang sebagai bagian dari masyarakat, dihadapkan pada berbagai permasalahan yang ada dan terjadi di lingkungan sekitarnya. 
Zubaedi (2011:287) menjelaskan bahwa "IPS mmepunyai tugas mulia dan menjadi fondasi penting bagi pengembangan intelektual, emosional, kultural, dan sosial peserta didik, yaitu mampu menumbuhkembangkan cara berpikir, bersikap dan berperilaku yang bertanggung jawab selaku individu, warga masyarakat, warga negara, dan warga dunia". Tujuan utama pembelajaran IPS ialah untuk mengembangkan potensi peserta didik agar peka terhadap masalah sosial yang terjadi di masyarakat, memiliki sikap mental positif terhadap perbaikan segala ketimpangan yang terjadi sehari-hari baik yang menimpa dirinya sendiri maupun yang menimpa masyarakat (Susanto, 2013). Tujuan pembelajaran IPS yang tercantum dalam kurikulum, adalah agar siswa mampu mengembangkan pengetahuan dan keterampilan dasar yang berguna bagi dirinya dalam kehidupan sehari-hari. Hal ini berarti, tujuan Pendidikan IPS bukan hanya sekedar membekali siswa dengan berbagai informasi yang bersifat hafalan (kognitif) saja, akan tetapi Pendidikan IPS harus mampu mengembangkan keterampilan berpikir, agar siswa mampu mengkaji berbagai kenyataan sosial beserta permasalahannya (Susanto, 2013).

Vera (2012) mengemukakan beberapa tujuan pokok mengajar di luar kelas diantaranya adalah kegiatan belajar mengajar di luar kelas bertujuan menyediakan latar (setting) yang berarti bagi pembentukan sikap dan mental peserta didik, apresiasi dan pemahaman peserta didik terhadap lingkungan sekitarnya, memberikan konteks dalam proses pengenalan berkehidupan sosial dalam tataran praktik (kenyataan di lapangan), mengenalkan berbagai kegiatan di luar kelas yang dapat membuat pembelajaran lebih kreatif, memberikan kontribusi penting dalam rangka membantu mengembangkan hubungan guru dan murid, memanfaatkan sumber-sumber yang berasal dari lingkungan dan komunitas sekitar untuk pendidikan, dan dengan mempermudah peserta didik dapat memahami secara optimal seluruh mata pelajaran. Selain itu dengan pembelajaran di luar kelas, guru bisa lebih mudah menciptakan suasana belajar yang menyenangkan bagi para siswa. Semuanya itu berdampak baik terhadap suasana belajarmengajar yang nantinya dapat meningkatkan minat siswa dalam belajar dan tentunya akan berpengaruh terhadap pencapaian kompetensi siswa. Mengajak siswa belajar di luar kelas menjadi salah satu upaya pembelajaran akan menjadi lebih bermakna, efektif dan menyenangkan. Pembelajaran di luar kelas yang akan dikolaborasikan dengan penerapan model pembelajaran Active Debate (Debat Aktif) ini akan dibatasi pada lingkungan di sekitar sekolah.

Adapun langkah-langkah penerapan pembelajaran model Active Debate (Debat Aktif) bernuansa Outdoor Study yakni a) Guru membagi kelompok peserta debat yang satu pro dan yang lainnya kontra dan mengajak siswa keluar kelas untuk melaksanakan pembelajaran diluar kelas (outdoor study), b) Guru memberikan tugas untuk membaca materi yang akan di debatkan kedua kelompok di atas dan memberikan kesempatan kepada siswa untuk mencari permasalahan yang akan dibahas dengan memanfaatkan lingkungan sekitar sebagai sumber belajar, c) Setelah selesai membaca materi dan mencari informasi sesuai dengan yang ditemukan pada lingkungan sekitar (sumber belajar). Guru menunjuk salah satu anggota kelompok pro untuk berbicara saat itu ditanggapi atau dibalas oleh kelompok kontra demikian seterusnya sampai sebagian besar siswa bisa mengemukakan pendapatnya, d) Sementara siswa menyampaikan gagasannya, guru menulis inti/ide-ide dari setiap pembicaraan di papan tulis sampai sejumlah ide yang diharapkan guru terpenuhi, e) Guru menambahkan konsep/ide yang belum terungkap, f) Dari data-data di papan tersebut, guru mengajak siswa membuat kesimpulan/rangkuman yang mengacu pada topik yang ingin dicapai.

Model pembelajaran Active Debate (Debat Aktif) bernuansa outdoor study menekankan kepada aktivitas siswa secara maksimal untuk menemukan konsep atau ide yang mengacu pada topik yang ingin disampaikan dibantu dengan pelaksanaan belajar di luar kelas. Dengan ungkapan lain, model pembelajaran ini menempatkan siswa sebagai subjek belajar. Dalam proses pembelajaran siswa tidak hanya berperan sebagai penerima pembelajaran melalui penjelasan guru secara verbal, tetapi juga berperan untuk menemukan sendiri inti dari materi pembelajaran tersebut melalui interaksi antara siswa dengan siswa, siswa dengan guru maupun siswa dengan 
lingkungan alam sebagai sumber belajar serta tercapainya tujuan pembelajaran. Pembelajaran seperti ini, diharapkan dapat berpengaruh pada kompetensi pengetahuan IPS.

Pernyataan tersebut juga didukung dengan hasil penelitian yang dilakukan oleh Febryaningsih (2016) yang menyimpulkan bahwa model pembelajaran Active Debate (Debat Aktif) dapat meningkatkan keterampilan berbicara siswa kelas V tahun pelajaran 2015/2016 di SD Negeri 1 Banjar Bali, Kecamatan Buleleng. Serta Penelitian yang dilakukan oleh Trisnayanti (2017) yang menyimpulkan bahwa model pembelajaran Inkuiri Bernuansa Outdoor Study berpengaruh terhadap penguasaan kompetensi pengetahuan IPA siswa kelas V SD Negeri Gugus Budi Utomo Tahun Ajaran 2016/2017.

\section{METODE}

Penelitian ini dilaksanakan pada semester 2 tahun ajaran 2018/2019 di kelas V SD N Gugus Kapten Japa. Jenis penelitian yang digunakan adalah penelitian kuantitatif yaitu penelitian eksperimen dengan desain eksperimen semu (quasy experimental design). "Desain ini mempunyai kelompok kontrol, tetapi tidak bisa sepenuhnya mengontrol variabel-variabel luar yang mempengaruhi pelaksanaan eksperimen" (Sugiyono, 2017:77). Hal ini dikarenakan kemampuan peneliti dalam mengamati perilaku siswa sangat terbatas terutama ketika siswa berada di luar sekolah (rumah), peneliti juga tidak memiliki kemampuan untuk mengetahui persepsi siswa terhadap perlakuan secara pasti. Bentuk desain eksperimen semu (Quasy Experimental Design) yang digunakan dalam penelitian ini yaitu Non-Equivalent Control Group Design.

Pada bentuk Non-Equivalent Control Group Design, terdapat dua kelompok sampel yang terdiri dari kelompok eksperimen dan kelompok kontrol sebagai subyek penelitian yang akan dibandingkan. Kelompok eksperimen dan kelompok kontrol yang digunakan sudah terbentuk tanpa adanya campur tangan peneliti dan tidak dilakukan random individual karena tidak mungkin mengacak kelas yang sudah terstruktur oleh sekolah. Secara skematis, desain eksperimen semu (quasy eksperimental design) yang digunakan pada penelitian ini dapat diilustrasikan sebagai berikut.

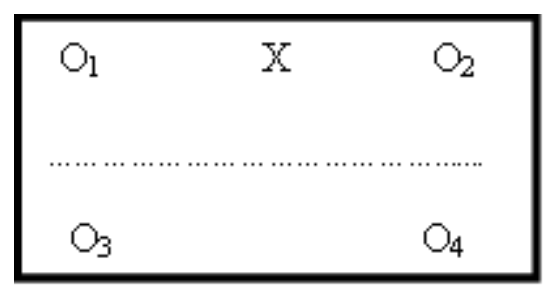

Gambar 1. Non-Equivalent Control Group Design

(Sumber: Sugiyono, 2017:79)

Pre test diberikan untuk kelompok kontrol dan kelompok eksperimen. Pre test hanya dilakukan sebagai penyetaraan kelompok. Teknik yang digunakan dalam penyetaraan kelompok adalah dengan menggunakan uji-t. Setelah itu peneliti memberikan perlakuan, yaitu dengan memberikan model pembelajaran Active Debate (Debat Aktif) bernuansa outdoor study kepada kelompok eksperimen dan memberikan pembelajaran konvensional kepada kelompok kontrol. 
Kemudian setelah diberikan perlakuaan, dilakukan post test untuk mengetahui kompetensi pengetahuan IPS. Prosedur yang ditempuh dalam penelitian ini terdiri dari tiga tahapan, yaitu persiapan, pelaksanaan dan akhir.

Pada tahap persiapan, kegiatan yang dilakukan yakni: (1) melakukan wawancara dengan ketua Gugus Kapten Japa dan guru kelas V di masing-masing sekolah di Gugus Kapten Japa untuk mengetahui ada atau tidaknya kelas unggulan di sekolah dasar yang ada di Gugus Kapten Japa Tahun Ajaran 2018/2019, (2) menyusun RPP (Rencana Pelaksanaan Pembelajaran), (3) mempersiapkan model pembelajaran active debate (debat aktif) bernuansa outdoor study, (4) mengkonsultasikan instrumen penelitian pre test dan post test bersama guru kelas dan dosen pembimbing, (5) mengkonsultasikan RPP bersama guru kelas dan dosen pembimbing, (6) mengadakan uji coba instrumen penelitian, (7) menentukan sampel penelitian berupa kelas dari populasi dan menentukan kelompok kelas eksperimen dan kelompok kelas kontrol melalui pengundian dengan teknik random sampling. Pada tahap pelaksanaan, kegiatan yang akan dilakukan yaitu: (1) memberikan pre test untuk mengetahui kemampuan awal siswa pada kelompok kontrol dan kelompok eksperimen, (2) memberikan perlakuan pada kelas eksperimen berupa model pembelajaran active debate (debat aktif) bernuansa outdoor study dan pada kelas kontrol dilaksanakan pembelajaran menggunakan pendekatan saintifik, perlakuan akan diberikan sebanyak 6 kali di kelas eksperimen dan 6 kali di kelas kontrol dengan menyesuaikan jam pelajaran, (3) memberikan post test pada akhir eksperimen, baik untuk kelompok eksperimen maupun kelompok kontrol. Saat tahap akhir, kegiatan yang ditempuh yaitu menganalisis data hasil penelitian dan melakukan uji hipotesis.

Populasi dalam penelitian ini adalah seluruh kelas V SD N Gugus Kapten Japa tahun ajaran 2018/2019, yang terdiri dari 12 kelas dalam 6 sekolah dasar. Populasi penelitian ini sebanyak 488 orang. Berdasarkan informasi yang diperoleh dari ketua gugus, kepala sekolah serta guru kelas di masing-masing SD N Gugus Kapten Japa bahwa kelas V di 6 sekolah dengan 12 kelas yang ada di Gugus Kapten Japa secara akademik yang memiliki nilai rata-rata tidak jauh berbeda. Dikatakan setara, karena pengelompokkan siswa ke dalam kelas-kelas dari 6 sekolah yang ada disebar secara merata antara siswa yang memiliki kemampuan tinggi, sedang dan rendah. Dari keterangan tersebut, berarti tidak terdapat kelas unggulan maupun non unggulan.

Setelah mengetahui populasi langkah selanjutnya adalah menentukan sampel penelitian. Penentuan sampel dilakukan dengan menggunakan teknik random sampling yang dirandom kelasnya, sehingga setiap kelas mendapatkan peluang yang sama untuk menjadi sampel penelitian. Cara undian dilakukan dengan menulis semua kelas V di seluruh SD N Gugus Kapten Japa pada masing-masing kertas yang jumlahnya 12 kelas, kemudian kertas di gulung. Masukkan gulungan kertas ke dalam kotak dan lakukan pengundian. Pengambilan undian dilakukan secara acak dengan mengambil 2 kali undian tanpa mengembalikan undian pertama yang diambil. Berdasarkan hasil random, di dapat 2 kelas yang akan dijadikan sampel penelitian. Sampel yang diperoleh dari hasil random adalah kelas VB SD N 17 Dauh Puri berjumlah 42 siswa dan kelas V SD N 20 Dangin Puri berjumlah 36 siswa. Selanjutnya diberikan pre test pada masing-masing kelas. Nilai yang diperoleh dari hasil pre test akan dijadikan nilai awal untuk menganalisis data gain skor ternormalisasi dari kelas eksperimen dan kelas kontrol menggunakan teknik undian dengan hasil kelas VB SD N. 17 Dauh Puri sebagai kelas eksperimen dan kelas V SD N. 20 Dangin Puri sebagai kelas kontrol. Dimana kelas eksperimen yang akan diberikan perlakuan dengan menerapkan model pembelajaran active debate (debat aktif) bernuansa outdoor study dan kelas kontrol yang dibelajarkan dengan pembelajaran sebagaimana kesehariannya.

Dalam penelitian ini, kontrol validitas internal dan kontrol validitas eksternal yang memengaruhi suatu penelitian. Validitas penelitian dapat dibedakan menjadi dua, yaitu validitas internal dan eksternal. Validitas internal dalam penelitian ini yaitu karakterstik subjek, sejarah (history), kematangan, testing dan instrumentasi, Sedangkan validitas eksternal dalam penelitian 
ini yaitu Interaksi antara perlakuan dan orang, interaksi antara perlakuan dan latar, pengaruh interaksi antara perlakuan dan waktu.

Data yang akan dianalisis dalam penelitian ini adalah kompetensi pengetahuan IPS siswa, untuk mendapatkan data tersebut digunakan tes kompetensi pengetahuan IPS. Tes yang digunakan untuk mengukur kompetensi pengetahuan IPS siswa berupa tes objektif. Bentuk tes yaitu pilihan ganda biasa. Dan tes ini digunakan dua kali, pertama pada saat pemberian pre test dan setelah diberian treatment pada saat pemberian post test. Sebelum tes dapat dilaksanakan, terlebih dahulu tes harus memenuhi syarat validitas, daya beda, indeks kesukaran dan reliabilitas.

Sebelum dilakukan pengujian hipotesis, maka terlebih dahulu dilakukan pengujian prasyarat analisis data meliputi dua bagian yaitu uji normalitas menggunakan rumus kolmogorovsmirnov dan uji homogenitas menggunakan uji $\mathrm{F}$ varians, setelah memenuhi uji prasyarat dimana data hasil pre test kompetensi pengetahuan IPS memenuhi persyaratan yaitu data berdistribusi normal serta dikategorikan homogen.

Selanjutnya dapat melanjutkan hipotesis yaitu menggunakan teknik analisis statistik parametrik yang digunakan untuk menguji hipotesis. Dalam penelitian ini dilakukan uji hipotesis dari data hasil skor post test untuk mengetahui terdapat tidaknya perbedaan kompetensi pengetahuan IPS menggunakan rumus uji t.

Data untuk mengetahui peningkatan pemahaman siswa mengenai materi yang telah dipelajari dapat diketahui dari normalitas gain skor yaitu, nilai pre test yang diperoleh dari kedua kelompok eksperimen dan kontrol dilakukan normalitas gain skor dengan nilai post test dari kedua kelompok eksperimen dan kontrol dengan menggunakan rumus sebagai berikut.

GSn

Gain Skor

Skormax-Skorpretest

(1)

Keterangan :

GSn $\quad=$ Gain Skor yang dinormalisasi

Gain Skor = Hasil dari skor pre test-post test

Skor max $=$ Skor maksimal

Skor pre test $\quad=$ Skor pre test

Hasil yang sudah didapat dianalisis menggunakan statistik inferensial. Teknik statistik inferensial digunakan untuk menguji kebenaran hipotesis penelitian dan hasilnya dapat digeneralisasikan. Data yang akan dianalisis harus memenuhi beberapa persyaratan yaitu uji normalitas sebaran data dan uji homogenitas varians. Uji normalitas sebaran data menggunakan teknik kolmogorov-smirnov untuk mengetahui apakah sebaran data skor kompetensi pengetahuan IPS siswa masing-masing kelompok berdistribusi normal atau tidak sehingga dapat menentukan teknik analisis datanya. Kriteria pengujian pada taraf signifikansi 5\% jika harga nilai maksimum $\left|F_{r}-F_{s}\right| \leq$ harga tabel Kolmogorov-Smirnov, maka $\mathrm{H}_{0}$ diterima dan data berdistribusi normal. Sedangkan jika harga nilai $\left|F_{r}-F_{s}\right|$ maksimum > harga nilai tabel Kolmogorov-Smirnov, 
maka $\mathrm{H}_{0}$ ditolak dan data tidak berdistriusi normal. Sedangkan uji homogenitas varians dipergunakan untuk mengetahui sama atau homogennya nilai secara statistik. Salah satu uji homogenitas varians dilakukan untuk menunjukkan bahwa perbedaan yang terjadi pada uji hipotesis benar-benar terjadi akibat adanya perbedaan varians antar kelompok, bukan sebagai akibat perbedaan dalam kelompok. Uji homogenitas dapat dilakukan apabila kelompok data tersebut berdistribusi normal. Uji homogenitas varians dilakukan dengan Uji Fisher (F). Pengujian dilakukan pada taraf signifikansi $5 \%$ dengan derajat kebebasan untuk pembilang $\mathrm{n}_{1}-1$ dan derajat kebebasan untuk penyebut $n_{2}-1$. Kriteria pengujian, jika $F_{\text {hit }}<F_{\text {tabel }}$ maka sampel homogen.

Setelah uji prasyarat terpenuhi maka uji hipotesis dengan menggunakan statistik parametrik dapat dilakukan. Analisis statistik yang digunakan untuk menguji hipotesis penelitia adalah uji beda mean (Uji t). Karena jumlah anggota sampel penelitian ini $n 1 \neq n 2$ dan varians homogen, maka digunakan uji-t dengan rumus polled varians. Kriteria yang dipergunakan pada taraf $5 \%$ dengan $d k=n 1+n 2-2$ adalah jika harga $t_{\text {hitung }} \leq t_{\text {tabel }}$, maka $\mathrm{H}_{0}$ diterima dan $\mathrm{H}_{\mathrm{a}}$ ditolak, dan jika harga $t_{\text {hitung }}>t_{\text {tabel, }}$, maka $\mathrm{H}_{0}$ ditolak dan $\mathrm{H}_{\mathrm{a}}$ diterima.

\section{HASIL DAN PEMBAHASAN}

Berdasarkan hasil perhitungan diperoleh rata-rata gain skor ternormalisasi kompetensi pengetahuan IPS siswa kelompok eksperimen yang dibelajarkan dengan model pembelajaran active debat (debat aktif) bernuansa outdoor study memiliki rata-rata sebesar 0,50 dengan varians 0,018 dan standar deviasi 0,13 . Sedangkan hasil perhitungan diperoleh rata-rata gain skor ternormalisasi kompetensi pengetahuan IPS siswa kelompok kontrol yang dibelajarkan secara konvensional memiliki rata-rata sebesar 0,42 dengan varians 0,019 dan standar deviasi 0,14. Dari hasil data perhitungan yang diperoleh, menunjukkan bahwa gain skor kompetensi pengetahuan IPS siswa kelompok eksperimen yang mengikuti pembelajaran menggunakan model pembelajaran active debat (debat aktif) bernuansa outdoor study memiliki nilai rata-rata lebih tinggi daripada kelompok kontrol. Sebelum dilakukan uji hipotesis terlebih dahulu dilakukan uji prasyarat analisis yaitu uji normalitas dan uji homogenitas varians.

Uji normalitas dilakukan untuk mengetahui apakah sebaran data skor kompetensi pengetahuan IPS siswa kelompok eksperimen dan kelompok kontrol berdistribusi normal atau tidak. Uji normalitas sebaran data yang digunakan dalam penelitian ini adalah uji KolmogorovSmirnov, dengan kriteria pengujian $\left|\mathrm{F}_{\mathrm{t}}-\mathrm{F}_{\mathrm{s}}\right|$ terbesar $\leq$ nilai tabel Kolmogorov-Smirnov, maka data berdistribusi normal.

Berdasarkan perhitungan hasil uji normalitas sebaran data nilai GSn kompetensi pengetahuan IPS pada kelompok eksperimen, diperoleh Nilai |FT-FS | Terbesar $=0,083$ dengan nilai tabel Kolmogrov-Smirnov $=0,209$, Nilai $\mid$ FT-FS $\mid$ Terbesar $=0,083<$ nilai tabel KolmogrovSmirnov $=0,209$ maka data berdistribusi normal, sedangkan berdasarkan perhitungan hasil uji normalitas sebaran data nilai GSn kompetensi pengetahuan IPS pada kelompok kontrol, diperoleh Nilai $\mid$ FT-FS | Terbesar $=0,101$ dengan nilai tabel Kolmogrov-Smirnov $=0,221$, Nilai |FT-FS | Terbesar = 0,101 < nilai tabel Kolmogrov-Smirnov = 0,221 maka data berdistribusi normal.

Uji homogenitas varians dilakukan terhadap data kompetensi pengetahuan IPS antara kelompok eksperimen dan kelompok kontrol. Pengujian homogenitas varians menggunakan uji $\mathrm{F}$ pada taraf signifikansi 5\%. Berdasarkan hasil analisis, diperoleh $\mathrm{F}_{\text {hitung }}=1,06$ dan $\mathrm{F}_{\text {tabel }}=1,73$

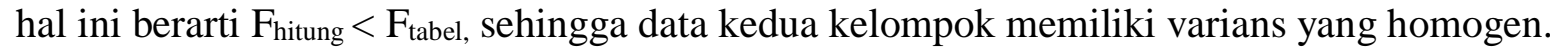

Berdasarkan hasil uji prasyarat yang terdiri uji normalitas dan uji homogenitas varians, dapat disimpulkan bahwa data kelompok eksperimen dengan kelompok kontrol berdistribusi normal dan memiliki varians yang homogen dengan demikian uji hipotesis menggunakan uji-t dapat dilakukan. 
Adapun hipotesis penelitian yang akan diuji berbunyi tidak terdapat perbedaan yang signifikan kompetensi pengetahuan IPS kelompok siswa yang dibelajarkan menggunakan model pembelajaran active debate (debat aktif) bernuansa outdoor study dengan kelompok siswa yang dibelajarkan secara konvensional pada siswa kelas V SD N Gugus Kapten Japa Tahun 2018/2019. Uji hipotesis dilakukan dengan menggunakan analisis uji-t. Kriteria yang dipergunakan pada taraf $5 \%$ dengan $\mathrm{dk}=\mathrm{n} 1+\mathrm{n} 2-2$ adalah jika harga $\mathrm{t}_{\text {hitung }} \leq \mathrm{t}_{\text {tabel }}$, maka $\mathrm{H}_{0}$ diterima dan $\mathrm{H}_{\mathrm{a}}$ ditolak, dan jika harga $t_{\text {hitung }}>t_{\text {tabel, }}$, maka $\mathrm{H}_{0}$ ditolak dan $\mathrm{H}_{\mathrm{a}}$ diterima.

Hasil analisis uji-t diperoleh $t_{\text {hitung }}=2,667$. Harga tersebut kemudian dibandingkan dengan harga $t_{\text {tabel }}$ dengan $\mathrm{dk}=41+35-2=76$ dan taraf signifikansi $5 \%$ sehingga diperoleh harga $t_{\text {tabel }}=$ 2,000 , karena $t_{\text {hitung }}>t_{\text {tabel, }}, t_{\text {hitung }}=2,667>t_{\text {tabel }}=2,000$ maka $H_{0}$ ditolak. Hal ini berarti terdapat perbedaan yang signifikan kompetensi pengetahuan IPS kelompok siswa yang dibelajarkan menggunakan model pembelajaran active debate (debat aktif) bernuansa outdoor study dengan kelompok siswa yang dibelajarkan secara konvensional pada siswa kelas V SD N Gugus Kapten Japa Tahun 2018/2019. Hasil uji hipotesis dapat dilihat pada tabel 1.

Tabel 1.

Rekapitulasi Hasil Analisis Uji-t Kelompok Sampel Penelitian

\begin{tabular}{|c|c|c|c|c|c|c|c|}
\hline No & Sampel & $\mathrm{N}$ & $\mathrm{dk}$ & $\bar{x}$ & $t_{\text {hitung }}$ & $t_{\text {tabel }}$ & Keterangan \\
\hline 1 & $\begin{array}{l}\text { Kelompok } \\
\text { Eksperimen }\end{array}$ & 42 & \multirow{2}{*}{76} & 0,50 & \multirow{2}{*}{2,667} & \multirow{2}{*}{2,000} & \multirow{2}{*}{$\mathrm{H}_{0}$ ditolak } \\
\hline 2 & $\begin{array}{c}\text { Kelompok } \\
\text { Kontrol }\end{array}$ & 36 & & 0,42 & & & \\
\hline
\end{tabular}

Dari hasil perhitungan diketahui bahwa sebaran data hasil post test pada kedua kelompok berdistribusi normal dan memiliki varians yang homogen. Karena data pada kelompok eksperimen dan kelompok kontrol telah memenuhi semua prasyarat, selanjutnya dilakukan analisis dengan menggunakan uji-t.

Rerata kompetensi pengetahuan IPS siswa kelompok eksperimen $=0,50>0,42$ rerata kompetensi pengetahuan IPS siswa kelompok kontrol. Sehingga dapat disimpulkan bahwa terdapat perbedaan penerapan model pembelajaran active debate (debat aktif) bernuansa outdoor study dengan kelompok siswa yang dibelajarkan secara konvensional pada siswa kelas $\mathrm{V}$ SD N Gugus Kapten Japa Tahun 2018/2019.

Berdasarkan hasil temuan tersebut, perolehan data kompetensi pengetahuan IPS pada kedua kelompok dapat diketahui bahwa kedua kelompok yang awalnya memiliki kemampuan setara, lalu setelah diberikan perlakuan yang berbeda, kompetensi pengetahuan IPS siswa pada kelompok eksperimen lebih baik apabila dibandingkan dengan kompetensi pengetahuan IPS siswa pada kelompok kontrol. Hal ini disebabkan oleh pembelajaran yang diterapkan pada kelompok eksperimen memiliki keunggulan. Kelompok eksperimen dibelajarkan dengan model pembelajaran active debate (debat aktif) bernuansa outdoor study memiliki nilai rerata yang lebih tinggi dibandingkan dengan kelompok kontrol yang menerapkan pembelajaran konvensional.

Hal ini dsebabkan oleh model pembelajaran active debate (debat aktif) bernuansa outdoor study merupakan suatu motivasi atau inovasi pembelajaran yang menekankan kepada aktivitas siswa secara maksimal untuk menemukan konsep atau ide yang mengacu pada topik yang ingin 
disampaikan dibantu dengan pelaksanaan belajar di luar kelas. Dengan ungkapan lain, model pembelajaran ini menempatkan siswa sebagai subjek belajar. Dalam proses pembelajaran siswa tidak hanya berperan sebagai penerima pembelajaran melalui penjelasan guru secara verbal, tetapi juga berperan untuk menemukan sendiri inti dari materi pembelajaran tersebut melalui interaksi antara siswa dengan siswa, siswa dengan guru maupun siswa dengan lingkungan alam sebagai sumber belajar serta tercapainya tujuan pembelajaran.

Kurniasih dan Sani (2015:64) menyebutkan kelebihan model pembelajaran active debate (debat aktif) yaitu sebagai berikut : (1) memantapkan pemahaman konsep siswa terhadap materi pelajaran yang telah diberikan, (2) melatih siswa untuk bersikap kritis terhadap semua teori yang telah diberikan, (3) melatih siswa untuk berani mengemukakan pendapat.

Selain itu proses pembelajaran menjadi kondusif karena dipadukan dengan pembelajaran di luar kelas (outdoor study). Hal tersebut dikarenakan oleh dalam proses pembelajaran siswa tidak hanya berinteraksi dengan antar siswa dan guru, melainkan mereka juga melakukan interaksi dengan lingkungan sekitar sebagai sumber belajar. Hal tersebut dapat menimbulkan dan meningkatkan rasa semangat siswa dalam mengikuti pembelajaran. Berbeda pada kelompok kontrol, dengan pembelajaran konvensional sebagaimana biasa diterapkan pada kelompok kontrol. Hal ini disebabkan siswa yang kurang diberikan peranan dalam proses pembelajaran karena segala sesuatunya lebih banyak mendominasi pada guru sehingga siswa susah mengingat dan memahami sesuatu yang mereka terima, karena mereka tidak memahami dan tidak berperan didalamnya.

Dengan demikian, pembelajaran menggunakan model pembelajaran active debate (debat aktif) bernuansa outdoor study pada penelitian ini memiliki keunggulan, yaitu siswa dapat mengungkapkan pendapatnya secara lisan, sehingga merupakan strategi yang secara aktif melibatkan setiap siswa, siswa dapat menemukan sendiri inti dari materi pembelajaran melalui interaksi antara siswa dengan siswa, siswa dengan guru dan siswa dengan lingkungan sebagai sumber belajar dan siswa tidak merasa jenuh dalam suasana belajar yang monoton. Sehingga siswa lebih aktif dalam berpikir dan mau berpartisipasi dalam proses pembelajaran.

Hasil temuan penelitian pada penelitian ini memiliki persamaan dengan penelitian yang relevan sebelumnya dan memperkuat hasil penelitian yang diperoleh. Hal ini didukung hasil penelitian yang diajukan oleh Febryaningsih (2016) yang mengungkapkan bahwa model pembelajaran active debate (debat aktif) dapat membantu siswa dalam memaksimalkan proses pembelajaran, dan untuk mencapai tujuan yang maksimal. Begitu pula dengan pembelajaran yang memanfaatkan lingkungan diluar kelas yakni pembelajaran bernuansa outdoor study sesuai dengan hasil penelitian yang diajukan Trisnayanti (2017) yang mengungkapkan bahwa pembelajaran diluar kelas (outdoor study) mampu meningkatkan minat siswa untuk belajar dan siswa dengan mudah memahami inti dari pembelajaran karena dapat secara langsung memanfaatkan lingkungan sekitar sebagai sumber belajar.

Berdasarkan uraian tersebut kelebihan pembelajaran menggunakan model pembelajaran active debate (debat aktif) bernuansa outdoor study pada muatan materi IPS pada penelitian ini memiliki keunggulan yakni dapat mengoptimalkan kemampuan berpikir siswa dalam proses pembelajaran dan saling bertukar pendapat dengan teman, serta didukung oleh peranan guru dalam pemberian pemantapan serta pengulangan materi yang dibuktikan dengan perbandingan rata-rata gain skor kompetensi pengetahuan IPS siswa. Dimana rata-rata gain skor kelompok eksperimen lebih tinggi dibandingkan nilai rata-rata kelompok kontrol.

\section{SIMPULAN}

Berdasarkan pengujian hipotesis dan pembahasan diketahui bahwa terdapat perbedaan yang signifikan kompetensi pengetahuan IPS kelompok siswa yang dibelajarkan dengan menggunakan model pembelajaran active debate (debat aktif) bernuansa outdoor study dengan 
kelompok siswa yang dibelajarkan secara konvensional pada siswa kelas V SD N Gugus Kapten Japa Tahun Ajaran 2018/2019. Hal ini dibuktikan dengan hasil analisis uji-t diperoleh uji $t_{\text {hitung }}=$ 2,667 pada taraf signifikansi $5 \%$ dengan $\mathrm{dk}=\mathrm{n} 1+\mathrm{n} 2-2=76$ diperoleh nilai $\mathrm{t}_{\text {tabel }}=2,000$ sehingga $t_{\text {hitung }}=2,667>t_{\text {tabel }}=2,000$, serta rata-rata gain skor ternormalisasi kompetensi pengetahuan IPS kelompok eksperimen $\bar{x}=0,50>\bar{x}=0,42$ rata-rata gain skor kompetensi pengetahuan IPS kelompok kontrol.

Sehingga dapat disimpulkan bahwa model pembelajaran active debate (debat aktif) bernuansa outdoor study berpengaruh terhadap kompetensi pengetahuan IPS siswa kelas V SD N Gugus Kapten Japa Tahun Ajaran 2018/2019.

Berdasarkan hasil penelitian ini, maka dapat diajukan beberapa saran sebagai tindak lanjut dari penelitian ini. Saran ini diajukan kepada berbagai kalangan diantaranya yakni kepada guru, dengan melalui penerapan model pembelajaran Active Debate (Debat Aktif) bernuansa outdoor study sesuai dengan hasil penelitian ini dapat digunakan sebagai alternatif dan masukan untuk menambah pengetahuan dan wawasan mengenai inovasi untuk muatan materi IPS. Kepada kepala sekolah, melalui hasil penelitian ini dapat dijadikan sebagai pertimbangan dalam pengambilan kebijakan penggunaan model pembelajaran. Dan saran kepada peneliti lain, melalui hasil penelitian ini dapat menjadi salah satu refrensi dalam mengembangkan penelitian selanjutnya.

\section{DAFTAR PUSTAKA}

Dirman dan Juarsih, Cicih. 2014. Pengembangan Kurikulum. Jakarta:PT. Rineka Cipta.

Febryaningsih, Gusti Ayu Ketut Triana. 2016. Penerapan Model Pembelajaran Debat Aktif Untuk Meningkatkan Keterampilan Berbicara Siswa Kelas V SD. Jurnal Mimbar PGSD Universitas Pendidikan Ganesha volume 4 nomor 1 tahun 2016. Tersedia pada https://ejournal.undiksha.ac.id (diakses tanggal 20 November 2018).

Hamalik, Oemar. 2013. Kurikulum dan Pembelajaran. Jakarta: Bumi Aksara.

Kurniasih, Imas dan Berlin Sani. 2015. Ragam Pengembangan Model Pembelajaran Untuk Peningkatan Profesionalitas Guru. Kata Pena.

Kemendikbud. 2014. Permendikbud Nomor 103 Tentang Pembelajaran Pada Pendidikan Dasar Dan Pendidikan Menengah. Jakarta: Kementerian Pendidikan dan Kebudayaan.

Shoimin, Aris. 2014. 68 Model Pembelajaran Inovatif dalam Kurikulum 2013. Yogyakarta: Ar-Ruzz Media.

Silberman, Mel. 2007. Active Learning 101 Strategi Pembelajaran Aktif. Yogyakarta: Pustaka Insan Madani.

Sugiyono. 2017. Metode Penelitian Kuantitatif, Kualitatif, dan R \& D. Bandung: Alfabeta.

Susanto, Ahmad. 2013. Teori Belajar\&Pembelajaran di Sekolah Dasar. Jakarta: Kencana.

Trianto. 2012. Model Pembelajaran Terpadu. Jakarta: Bumi Aksara.

Trisnayanti, Kadek Dewi. 2017. Pengaruh Model Pembelajaran Inkuiri Bernuansa Outdoor Study Terhadap Penguasaan Kompetensi Pengetahuan IPA Siswa Kelas V. Jurnal Mimbar PGSD Universitas Pendidikan Ganesha volume 5 nomor 2 tahun 2017. Tersedia pada https://ejournal.undiksha.ac.id (diakses tanggal 20 November 2018). 
Vera, Adelia. 2012. Metode Mengajar Anak di Luar Kelas (outdoor study). Yogyakarta: Diva Press.

Zubaedi. 2011. Desain Pendidikan Karakter. Jakarta:Kencana. 